\title{
ROLLING CONTACT FATIGUE BEHAVIOR OF RAIL WELDMENTS UNDER VARIOUS LOAD CONDITIONS: IN INDIAN RAILWAYS ASPECT
}

\author{
PRAKASH KUMAR SEN ${ }^{1}$, MAHESH BHIWAPURKAR ${ }^{2}$ \& S.P HARSHA ${ }^{3}$
}

${ }^{1}$ Research Scholar, Mechanical Engineering Department, O.P. Jindal University Raigarh, India

${ }^{2}$ Professor, Mechanical Engineering Department, O.P. Jindal University Raigarh, India

${ }^{3}$ Professor, Department of Mechanical \& Industrial Engineering, IIT Roorkee, India

\begin{abstract}
Indian railway provides the necessary infrastructure for the rapid industrialization and economic development of the country, but in the recent times, accidents and derailments have serious affected its credibility. It was observed that the failure of rail causing an accident is largely associated with rail fatigue and joint failure i.e. weldments. The occurrence of defective rail weld and the associated increase in train accidents has emphasized the need, both from safety and operation viewpoints. Sometimes fresh weld failure causes the derailment. Since derailments are caused due to weldfailures and rail fractures, it is necessary to strengthen tracks by replacing the aging rails with new ones. The aim of the studyis to find the effect of higher axial load on rail/welds at various operating speed of train varying from 50 to 100 kmph. The study also discuss the various causes of defectoccurs in wheels and rails due to higher axle load. The recommendation had been provided to prevent the deterioration in rail/welds. The data were collected from multiple sources of Indian railways departments involved in rail track construction and maintenance activities with their experiences. The data of rail/weldfailure of in last 5 years for $52 \mathrm{~kg}$ and $60 \mathrm{~kg}$ rail section was obtained. Considering the importance of rail as an asset from both safety and reliability point of view for IR's operation of both passenger and freight trains on the same infrastructure, it is recommended to use $60 \mathrm{Kg}, 110 \mathrm{UTS}$ rail section.

KEYWORDS: Rolling Contact Fatigue (RCF), Rail Track, Rail Weldment, Wheel-Rail Contact
\end{abstract}

Received: Jun 06, 2020; Accepted: Jun 26, 2020; Published: Aug 31, 2020; Paper Id.: IJMPERDJUN2020976

\section{INTRODUCTION}

Today, Indian Railways (IR) set to embark new journey as the second largest network in the world, to carry over a millions of passenger and tons of freight every day. Besides being the largest mode of transportation. It was long known that majority of the existing tracks were designed before independence and based on the specifications which better suited that time, standard has been adopted. For decades continuous improvement has been exported and interpreted to track system like PSC sleepers, CMS crossing, LWR, mechanized track maintenance, better fasteners etc., to keep pace with increasing axle load and speed. The Indian government is undertaking several initiatives as to upgrading its aged railway infrastructure for heavy axle loads at a very fast pace and enhance its quality of construction.

The rail construction under the highest axle load is exposed to heavy loads, wear and deformation. Obviously, increased stresses result in faster deterioration in track geometry which results in increase in track maintenance. Both freight and passenger traffic causes impact loads due to track and track irregularities, but the combined axle load and speed of the train makes the differences in cargo size and track damage becomes extremely 
complex. High-axle freight loads are larger and longer than high-speed trains. The rolling contact fatigue (RCF) is one of the most important rail failure mechanisms with significant cost and safety risks for rail system operation. RCF is a kind of reversal of stresses may initiate crack in the wheel and cause fracture of the wheel. The crack can be on surface or subsurface. Joining rails by improper welding also introduces a variety of defects on the joints as well as in the heat affected zone (HAZ). Many kind of contact stress which is helpful for studying wheel/rail interaction was reported by [1]. The stresses present in the contact area which is significant for material strength was studied by [2]. A technique was developed to use a real time fault detection to estimate creep forces of the wheel-rail contact [3]. With an increase in axle load stresses may attain values up to plastic limit.

In respect to wear which is a slow deterioration process, fatigue causes catastrophic failure and fracture in wheels with loss of large material from tread. The wear of the rail head can lead to changes in the rail profile and a reduction in the cross-sectional area of the rail head, which can affect the state of stress underload conditions during operation. However, excessive wear in combination with a defect that increases the risk of fatigue cracks can pose an even greater risk [4]. Rail resistance to rail wear limits was investigated based on internal transverse defects in North American rail systems [5]. Based on laboratory and field conditions, rail load levels has been measured under fatigue behavior of the rail material to define acceptable rail wear limits for high axle load conditions [6].

For crack investigation it is important to study the nature of crack, shape, size where it is located. At the outset it should be detected in a routine checkup or on a failed component. Many studies of the literature have been carried out to understand the crack, subsurface crack behavior and its propagation. For fatigue analysis, there are three phases a) Fatigue initiation, b) Crack propagation, c) Fatigue fracture, which have their occurrence time. If it is able to predict the Initiation of fatigue, it can be helpful in increased life of the wheel and optimize for various parameters [7]. There has been extensive research to predict the stresses in elastic-plastic condition and their influence on crack propagation. The residual stress and strain was investigated to predict fatigue life by applying a three-dimensional elastic-plastic rolling-sliding contact problem on a quarter space to approximate wheel-rail contact [8]. It has been observed from literature that very little work has been reported on optimization of weight of railway wheel. Due to increase in critical speed and axle load, the geometry of the wheel and shape of the wheel are to be designed well.

In this paper, the effect of higher axial load (25 Tonnes) on rail/welds for various operating speed varying has been studied. This paper discussest from 50 to $100 \mathrm{kmph}$. The various causes of defect occurs in wheels and rails due to higher axle load. The recommendation had been suggested for propers election of the rail section to prevent the deterioration in rail/welds.

\section{METHODS}

Primarily in the last 5 years, rail/weld failure data of 25 Tonnes axle loading on both $52 \mathrm{~kg}$ and $60 \mathrm{~kg}$ rail section was collected in this study. The data were collected from multiple sources of Indian railways departments involved in rail track construction and maintenance activities [9-10]. The speed has been been monitored for the rail operation of the 25-tonneaxle loaded freight train for both rail sections, Table 1. In the present study, both the rail section was considered to be suitable for running of $25 \mathrm{~T}$ axle load trains at specified speed, for BOXN and similar type of wagons 
Table 1: Rail Parameter Under Study

\begin{tabular}{l|c|c|}
\hline \multicolumn{1}{|c|}{ Rail Section } & $\mathbf{6 0} \mathbf{~ k g}$, 90 UTS & 52 Kg 90 UTS* \\
\hline Sleepers and density & PSC, 1660 nos. per Km & PSC, 1540 nos. per Km \\
\hline Ballast cushion & $300 \mathrm{~mm}$ & $250 \mathrm{~mm}$ \\
\hline *Ultimate Tensile Strength
\end{tabular}

During the investigation, the data were collected from South East Central Railway (SECR), East Cost Railway (ECoR) and South Eastern Railway (SER), of 25 tonne axle load rakes consisting of various wagon types (BOBS, N-BOX, BOBSNM1, BOY, BOXNHL) and other iron ore-loadedrakes [9-10]. Generally one rake consists of about 58 wagons and capacity of each wagon is 55 tonnes. This study detrmine the strength of $60 \mathrm{~kg}$ rail section under25 Tonnes axle loading and probable solution has been proposed to ensure the safety of track infrastructure, as it has to carry passenger traffic also. The recommendation and suggestions for higher strength of rail section has been provided to support higher axle load based on failure trend and computation alanalysis.

\section{RESULTS AND DISCUSSIONS}

Based on the data provided by SEC Railway, Eco Railway and SE Railway [9-10], the effect of 25 T axle load dedicated rakes on Rail/Weld failure for $52 \mathrm{~kg} / 60 \mathrm{~kg}$ rail section has been discussed.

\section{Effect of 25 T Axle Load on Track Structure of SECR Section}

The $25 \mathrm{~T}$ axle load dedicated rake consisting of BOBSNM1 loaded with iron ore running with maximum speed of $50 \mathrm{kmph}$ in Maroda-Dallirajhara non-electrified section of SEC Railway is considered for study. The rail/weld failures details maintained separately for $52 \mathrm{~kg} / 60 \mathrm{~kg}$ rail section on single line of this route has been indicated in table 2 . Also the number of defects detected from ultrasonic flow detection for both rail sections has been tabulated in the table 2 .

Table 2: Rail/Weld Failures Details of SECR Section

\begin{tabular}{|c|c|c|c|c|c|c|c|c|c|c|c|}
\hline \multirow[t]{3}{*}{ S. No. } & \multirow[t]{3}{*}{ Year } & \multicolumn{4}{|c|}{$\begin{array}{c}\text { Rail/Weld Failure Details } \\
\text { Maintained Separately for } 52 \\
\text { kg/60 kg Rail Section }\end{array}$} & \multicolumn{6}{|c|}{ Nos. of Ultrasonic Flow Detection Defects Detected } \\
\hline & & \multicolumn{2}{|c|}{ Rail Failure } & \multicolumn{2}{|c|}{ Weld Failure } & \multicolumn{2}{|c|}{ IMR } & \multicolumn{2}{|c|}{ IMRW } & \multicolumn{2}{|c|}{ DFWR } \\
\hline & & $60 \mathrm{~kg}$ & $52 \mathrm{~kg}$ & $60 \mathrm{~kg}$ & $52 \mathrm{~kg}$ & $60 \mathrm{Kg}$ & $52 \mathrm{Kg}$ & $60 \mathrm{Kg}$ & $52 \mathrm{Kg}$ & $60 \mathrm{Kg}$ & $52 \mathrm{Kg}$ \\
\hline 1 & $2013-14$ & 0 & 0 & 0 & 0 & 0 & 0 & 01 & 0 & 0 & 0 \\
\hline 2 & $2014-15$ & 0 & 0 & 01 & 0 & 0 & 0 & 0 & 0 & 0 & 0 \\
\hline 3 & 2015-16 & 0 & 0 & 0 & 0 & 0 & 0 & 0 & 0 & 0 & 0 \\
\hline 4 & 2016-17 & 0 & 0 & 10 & 0 & 02 & 0 & 0 & 0 & 0 & 0 \\
\hline 5 & 2017-18 & 0 & 0 & 08 & 01 & 01 & 0 & 01 & 0 & 0 & 0 \\
\hline & Total & 0 & 0 & 19 & 01 & 03 & 0 & 01 & 0 & 0 & 0 \\
\hline
\end{tabular}

IMR Immediate Removal *IMRW Immediate removal of weld.

*DFWR A welded joint showing moving signals on Ultrasonic Flow Detection Defects (USFD) more than $60 \%$ of full screen height to be classified as DFWR.

\section{Effect of 25 T Axle Load on Track Structure of ECOR Section}

The $25 \mathrm{~T}$ axle load dedicated rake consisting of BOY, BOBNHL loaded with iron ore running with maximum speed of 65 $\mathrm{kmph}$ in Kottavalsa-kirandul electrified section of Eco Railway is considered for study. The rail/weld failures details maintained separately for $52 \mathrm{~kg} / 60 \mathrm{~kg}$ rail section on single line of this route has been indicated in table 3 . Also the number of defects detected from ultrasonic flow detection for both rail sections have been tabulated in the table 3 . 
Table 3: Rail/Weld Failures Details of ECOR Section

\begin{tabular}{|c|c|c|c|c|c|c|c|c|c|c|c|}
\hline \multirow{2}{*}{ S. No. } & \multirow{2}{*}{ Year } & \multicolumn{9}{|c|}{$\begin{array}{c}\text { Rail/Weld Failure Details } \\
\text { Maintained Separately for 52 } \\
\text { kg/60 kg Rail Section }\end{array}$} & \multicolumn{2}{c|}{ Nos. of Ultrasonic Flow Detection Defects Detected } \\
\cline { 3 - 15 } & & Rail Failure & Weld Failure & \multicolumn{2}{c|}{ IMR } & \multicolumn{2}{c|}{ IMRW } & \multicolumn{2}{c|}{ DFWR } \\
\hline & & $60 \mathrm{~kg}$ & $52 \mathrm{~kg}$ & $60 \mathrm{~kg}$ & $52 \mathrm{~kg}$ & $60 \mathrm{Kg}$ & $52 \mathrm{Kg}$ & $60 \mathrm{Kg}$ & $52 \mathrm{Kg}$ & $60 \mathrm{Kg}$ & $52 \mathrm{Kg}$ \\
\hline 1 & $2013-14$ & 01 & 0 & 15 & 0 & 01 & 0 & 01 & 0 & 0 & 0 \\
\hline 2 & $2014-15$ & 01 & 0 & 21 & 0 & 03 & 0 & 0 & 0 & 12 & 0 \\
\hline 3 & $2015-16$ & 01 & 0 & 05 & 0 & 03 & 0 & 02 & 0 & 01 & 0 \\
\hline 4 & $2016-17$ & 02 & 0 & 04 & 0 & 11 & 0 & 04 & 0 & 20 & 0 \\
\hline 5 & $2017-18$ & 02 & 0 & 16 & 0 & 59 & 0 & 04 & 0 & 163 & 0 \\
\hline & Total & 07 & 0 & 61 & 0 & 77 & 0 & 11 & 0 & 196 & 0 \\
\hline
\end{tabular}

\section{Effect of 25 T Axle Load on Track Structure of SER Section}

The $25 \mathrm{~T}$ axle load dedicated rake consisting of BOBS, N-BOX and other loaded with iron ore running with maximum specified speed in Bandamunda-Bimalgarh, Bimalgarh-Barsuan and Bimalgarh-Kiriburu, electrified section of SE Railway is considered for study. The rail/weld failures details maintained separately for $52 \mathrm{~kg} / 60 \mathrm{~kg}$ rail section on single line of this route has been indicated in table 4.

Table 4: Rail/Weld Failures Details of SER Section

\begin{tabular}{|c|c|c|c|c|c|c|c|}
\hline \multirow{3}{*}{ S. No. } & \multirow{3}{*}{ Year } & \multicolumn{3}{|c|}{$\begin{array}{c}\text { Bandamunda - Bimalgarh } \\
\text { Bimalgarh - Barsuan }\end{array}$} & \multicolumn{2}{c|}{ Bimalgarh - Kiriburu } \\
\cline { 3 - 8 } & & Rail/Weld Failure Details Maintained Separately for 52 kg/60 kg Rail Section \\
\cline { 3 - 8 } & & \multicolumn{2}{|c|}{ Rail Failure } & \multicolumn{2}{c|}{ Weld Failure } & Rail Failure & Weld Failure \\
\cline { 3 - 8 } & $\mathbf{6 0} \mathbf{~ K g}$ & $\mathbf{5 2} \mathbf{~ K g}$ & $\mathbf{6 0} \mathbf{~ K g}$ & $\mathbf{5 2} \mathbf{~ K g}$ & $\mathbf{6 0 ~ K g}$ & $\mathbf{6 0 ~ K g}$ \\
\hline 1 & $2013-14$ & 01 & 02 & 0 & 01 & 01 & 01 \\
\hline 2 & $2014-15$ & 0 & 01 & 01 & 01 & 0 & 01 \\
\hline 3 & $2015-16$ & 01 & 0 & 01 & 01 & 01 & 01 \\
\hline 4 & $2016-17$ & 0 & 0 & 0 & 0 & 0 & 01 \\
\hline 5 & $2017-18$ & 0 & 0 & 01 & 0 & 0 & 04 \\
\hline \multicolumn{2}{|c|}{ Total } & 02 & 03 & 03 & 03 & 02 & \\
\hline
\end{tabular}

The result observed from table 2-4, reported that the track deterioration in these sections was due to dropping of iron ore particles on rail surface during running of $25 \mathrm{~T}$ axle load dedicated rake. Due to iron ore particles falling on rail top from wagon and after passage of wagon, pitting was observed at rail top which may further reduce the service life of rail. It was also reported that an increase in axle load results in decrease in the fatigue life of rail, measured in terms of cumulative GMT and reduction occurs for both heavier as well as lighter sections. Therefore in the interest of long term economy and from fatigue considerations, the IR decided to use a heavier section rail of $60 \mathrm{Kg}, 90 \mathrm{UTS}$.

To determine the strength of rail section under train load, the various major stresses considered are; Bending Stress which occurs due to rail bending vertical downward under moving load, Temperature Stress in rail occurs due to continuous welding of rail, Residual Stress developed due to differential cooling and rolling of rail in steel mill. The table 5 shows stresses induced in $60 \mathrm{Kg}$ rail section under $25 \mathrm{~T}$ and $22.9 \mathrm{~T}$ axle loading for varying train speed from 50 to 100 $\mathrm{kmph}$. From the table 5, it was seen that $10 \%$ of yield strength is accounted for as unforeseen stresses that can't be assessed accurately. These are stresses due to bent rail in curves and due to one side to Sun and other to shadow side, etc. The calculated total stress includes the bending, residual, thermal and unforeseen stresses. Now almost all the new rails being manufactured are of 90 UTS. The yield strength was considered as 52\% of average value of observed UTS. It was observed from the table 5 and Figure 1 that the calculated total induced stresses in the $60 \mathrm{~kg}$ (90 UTS) rail section is either 
appoaching or crossed maximum permissible yield strength value. The weight of the rail section should not be such that the stresses exceed their permissible values and therefore it is advisable to adopt $60 \mathrm{Kg}$, 90UTS rail section.

It was concluded that the methodology employed by the IR for rail stress estimation is adequate, and is within accepted practices for rail strength design and section selection [9]. The result shows that the existing IR track structure, having a rail section of $60 \mathrm{~kg} / \mathrm{m}$ and $880 \mathrm{MPa}$ tensile strength, is not sufficient for $25 \mathrm{~T}$ axle load operations. Based on the calculated current estimates for rail stresses, adopting 1,080-MPa rail with a minimum yield strength in the range of 800 MPa provides wide coverage against a combination of the rail stresses and the potential for rail failures compared to 880MPa rail. It can take higher axle load at faster speeds. Therefore it is suggested to adopt standard higher strength rail section of $60 \mathrm{Kg}, 110 \mathrm{UTS}$ for long term economy and from fatigue considerations, also it require lesser works of track renewal.

There are large numbers of other stresses which are considered in some form at international level but not considered on IR. These are stresses due to cant deficiency on curves, lateral force being considered, consideration of section wear, considering differential temperature deg C, etc. As per the IR report, the current train speed upto $160 \mathrm{kmph}$ is permitted for passenger trains, having low axle loads of around $17 \mathrm{~T}$. There is a general observation that the operation of $25 \mathrm{~T}$ load is limited at $50 \mathrm{kmph}$ on some routes of IR and $22.9 \mathrm{~T}$ upto $75 \mathrm{kmph}$ is there on IR. The IR report suggested that the $25 \mathrm{~T}$ axle load is not permitted as the current rail section of IR $(60 \mathrm{~kg}, 880 \mathrm{Gr})$ does not have requisite yield strength. However, on ECoR the operation of $25 \mathrm{~T}$ is being done in on around $415 \mathrm{kms}$ line at $50 \mathrm{kmph}$.

Table 5: Stresses in $60 \mathrm{Kg}$ Rail Section Rail Under Axle Loading

\begin{tabular}{|l|c|c|c|c|c|c|c|c|c|}
\hline \multicolumn{1}{|c|}{ Speed, $\mathbf{k m p h}$} & $\mathbf{5 0}$ & $\mathbf{6 0}$ & $\mathbf{7 5}$ & $\mathbf{1 0 0}$ & $\mathbf{5 0}$ & $\mathbf{6 0}$ & $\mathbf{7 5}$ & $\mathbf{1 0 0}$ \\
\hline $\begin{array}{l}\text { Bending Stresses due to } \\
\text { wheel load }\end{array}$ & 10.51 & 10.79 & 11.23 & 12.51 & 9.68 & 9.93 & 10.34 & 11.51 \\
\hline Residual stress & \multicolumn{10}{|c|}{24.50} \\
\hline Thermal Stresses & \multicolumn{10}{|c|}{11.32} \\
\hline Unforeseen Condition & 1.05 & 1.08 & 1.12 & 1.25 & 0.97 & 0.99 & 1.03 & 1.15 \\
\hline Total Stress & 47.38 & 47.69 & 48.17 & 49.58 & 46.47 & 46.74 & 47.19 & 48.48 \\
\hline $\begin{array}{l}\text { Maximum permissible } \\
\text { Yield Strength) for } 90 \\
\text { UTS }\end{array}$ & \multicolumn{10}{|c|}{40.80} \\
\hline $\begin{array}{l}\text { Maximum permissible } \\
\text { (Yield Strength) for 110 } \\
\text { UTS }\end{array}$ & \multicolumn{10}{|c|}{57.1} \\
\hline
\end{tabular}




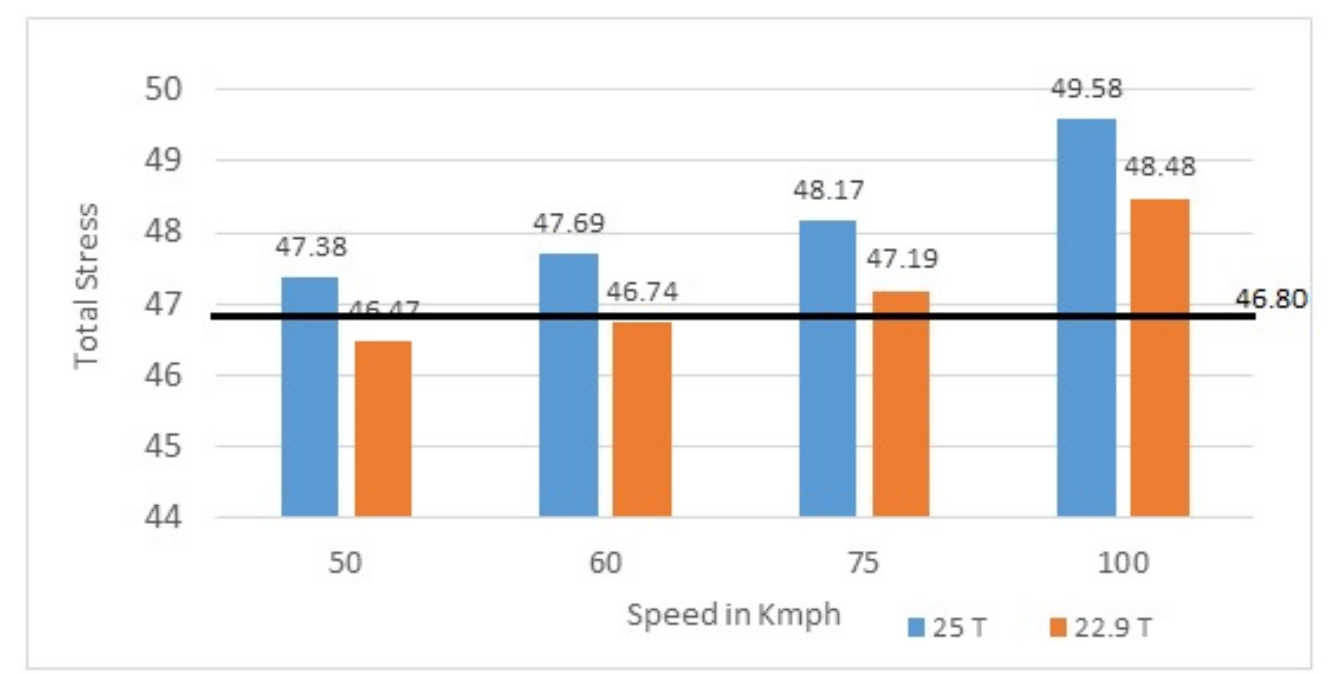
Figure 1: Variation of Total Induced Stress as Against Maximum Permissible Yield Strength
Under 25 T and 22.9 T Axle Loading for Varying Speed.

Additionally, the incremental strength increase from $880-\mathrm{MPa}$ rail will have a disproportionally positive impact on the 1,080-MPa rail's service life. This specification and procurement decision should be considered in terms of life cycle costs (LCC), but the benefits are likely to justify its worth. Additionally, this strength is similar (albeit $9 \%$ less) to what is used on at least two major Class I heavy axle load (HAL) freight railroads in the United States, which is the same as what is specified in AREMA (2017a). As a point of comparison, the standard grade used in the United States is of higher strength than the IR's 880-MPa rail.

In case of static stresses due to vertical bending, the heavier axle load means higher wheel load, which will result into higher bending moment and higher stress in rail. Therefore, there is a need to upgrade \& standardize the existing track structure for $25 \mathrm{t}$ axle load on IR. From the report of Indian railway [9-10], it was suggested that $60 \mathrm{~kg}$ (110 UTS) rail is more suitable in comparison to $60 \mathrm{~kg}$ (90UTS) rail for the Kottavalsa-kirandul electrified section of ECo Railway because wear of 110 UTS rail is 5 times lesser than 90 UTS rail.

The main concern of the track engineers in the field is that the track deterioration caused predominantly by freight trains becomes impediment to passenger trains. Most of the track deterioration is strongly associated to the development of dynamic loads resulting from the wheel-rail contact. These dynamic loads are influenced by many factors. Some important factors are axle load, speed of operation and dynamic augment of rolling stock, characteristics of rolling stock affecting dynamic behavior i.e. wheel diameter, suspension system, unsprung mass, etc., maintenance standards of rolling stock permissible size of wheel flat, wheel deformations and track structure, its geometry. It is pertinent to note that the increasing speed would lead to increase the dynamic effect which at higher speeds might cause the dynamic load equal to twice the static load. Adding to it, if the static load in itself is increased in case of high axle load, the dynamic effect at high speeds would be very high.

It is also stated that the increased loading speeds up the track deterioration rateof track geometry and fatigue life of rail welds was found to be significantly reduced, thus causing increase in number of rail/weld failure. Moreover, the dynamic augment (DA) is an out of balance force due to a parasitic movement like pitching, bouncing, rolling etc of running rail vehicle. It is transferred to the track by the driving wheel. The high speed means higher dynamic augment, which will result into higher bending moment and higher stress in rail. The Research Design and Standards Organisation 
(RDSO) report [10] indicates that a wheel flat of dimensions of $18 \times 25 \times 3 \mathrm{~mm}$ in ICF coach produced a dynamic augment (DA) as high as $257 \%$ at speed of $96 \mathrm{kmph}$ against the normal DA of $57.4 \%$. Therefore, it can be inferred that even a little deformation in wheel, will produce an instantaneous wheel load that rail stress crosses its permissible limit in 60 kgrail. Continuous operation at near limiting magnitude of rail stress could be severe for the track. In that case, the use of higher UTS shall be more of a liability than asset as they are prone to higher incidences of sudden failures, wheel scabs/burns leading to rather increased incidences of railfailures. The railways in various countries such as North America, Australia, South America, South Africa and Sweden operated the high axle loads to obtain significant overall savings in operating cost. These savings have been accomplished regardless of increased cost of maintaining tracks, greater track component damages and shorter component lives. The raising of the axle load from 22.5 tonnes to 30.5 tonnes yielded 40 per cent savings in transportation cost in the US [11].

\section{CONCLUSIONS}

The Railways' research arm RDSO, has warned against carrying heavy wagon till the existing rail tracks are upgraded. The result showed that the track on electric section Kottavalsa-kirandul of East-Coast Railway could not handle the higher axle loads. compared to the $60 \mathrm{~kg}$ rail (90 UTS), the $60 \mathrm{~kg}$ rail (110 UTS) is better suited for this section, as the wear of the 110 UTS rail is 5 times less than 90 UTS rails. Moving wagons with loads of over 22.9 tonnes per axle on Indian Railways' tracks was found to be unsafe. Therefore high strength rails with improved yield strength, fracture toughness, etc is suggested to carry heavier wagons with loads of 25 tonnes per axle. Using a $60 \mathrm{~kg}$ heavy 90 UTS rail, an increase in axle load results in a reduced rail life, Form the point of view of long-term economy, safety, reliability and fatigue, it is therefore recommended to use a $60 \mathrm{~kg}$ and 110 UTS heavy profile rail.

\section{REFERENCES}

1. K.L. Johnson, Contact Mechanics, Cambridge University Press, Cambridge, UK, 1985.

2. M. Pau., Aymerich, F., and Ginesu, F., Distribution of contact pressure in wheel-rail contact area, Wear, Vol. 253, No. 1-2, 2002, pp.265-274.

3. Sharma, Meenu, and Shahnwaz Alam. "Experimental Investigation of Mechanical Properties of Saw Weldments of IS-2062 Steel Plates. "International Journal of Mechanical and Production Engineering Research and Development (IJMPERD) 8. 4, Aug 2018, 1043-1048

4. G.R. Christopher P. Ward, Roger M. Goodall, and Roger Dixon, Contact Force Estimation in the Railway Vehicle Wheel-Rail Interface, Preprints of the 18th IFAC World Congress Milano (Italy) August 28 -September 2, 2011.

5. ML. Lyons, DY. Jeong, JE., Gordon Fracture Mechanics Approach to Estimate Rail Wear Limits. ASME Conference Proceedings, (48944):137-46, 2009.

6. Sunny, K. T., et al. "a Review on Mechanical \& Microstructural Property Evaluation of Aluminium 5083 Alloy Weldment." vol 3 (2013): 119-128.

7. Jeong DY, Tang YH, Orringer $O$. Estimation of rail head wear limits based on rail strength investigations, Office of research and development Washington, DC 20590, DOT/FRA/ORD- 98/07, DOT-VNTSC-FRA-98-13, Final report, December. 1998.

8. Marich S. Rail wear/fatigue limits: Thomas Telford Ltd, TrackTechnology, London, UK 1985.

9. Deepak, J R, et al. "Improvement of Weldment by Post Weld Heat Treatment of Low Carbon Steel."International Journal of Mechanical and Production Engineering Research and Development (IJMPERD) 9. 5, Oct 2019, 1249-1256 
10. Elena Kabo and Anders Ekberg, Fatigue initiation in railway wheels -a numerical study of the influence of defects, $J$ of Wear, Vol 253, No.1-2, July 2002, pp.26-34

11. Yu, C.-C., Keer, L.M., Moran, B., 1996, Elastic-plastic rolling-sliding contact on a quarter space, Wear, Vol. 191,pp.219-225.

12. Information on Indian Railway Report No. SECR/ENGG/BIA-II/PW/1/Pt-V/258, dated 01.02.2018 of ADEN/II/BIA/SECR.

13. Kumar, Mukesh, Naveen Rana, and M. Kannan. "Some Studies on the Performance of Activated-TIG Welding in Steel Weldments. "International Journal of Mechanical and Production Engineering Research and Development (IJMPERD), Apr 2019, 5-10

14. Information on Indian Railway Report No. E/2/KRPU/2018, dated 23.02.2018 of ADEN/KRPU/ECoR.

15. Information on www.iricen.gov.in > iricen > ipwe_seminar > skjha. 